\title{
SOCIAL BENEFITS IN THE LABOR LAW THE HUMAN RIGHT TO SOCIAL RIGHTS
}

\author{
ŚWIADCZENIA SPOŁECZNE W PRAWIE PRACY \\ PRAWEM CZŁOWIEKA DO SPOŁECZNYCH \\ PRAW SOCJALNYCH
}

\begin{abstract}
The issue of social benefits in labor law is an important research topic, and at the same time an extremely important and constantly current topic. In view of the importance of the employer's obligation to meet the life needs of employees that do not fall within the content of the employment relationship, i.e. in the sphere of mutual rights and obligations of the parties related to the employee's performance of paid work, the purpose of this study was to systematize and analyze a number of social benefits regulated by law work. The article presents a catalog of social benefits paid by the employer to the employee. The employer was obliged to provide them with benefits such as holiday pay, sick pay, pay for raising professional qualifications, parental protection benefits, pay for occasional layoffs, employee severance pay, compensatory allowances for specially protected employees, pay for occupational medicine examinations. , benefits paid under the Act on the Company Social Benefit Fund.
\end{abstract}

\section{STRESZCZENIE}

Problematyka świadczeń społecznych w prawie pracy to istotny w sensie badawczym, a przy tym niezmiernie ważny i nieprzerwanie aktualny temat. Wobec wagi istoty obowiązku pracodawcy zaspokajania potrzeb życiowych pracowników, które 
nie mieszczą się w treści stosunku pracy, czyli w sferze wzajemnych praw i obowiązków stron związanych $\mathrm{z}$ wykonywaniem przez pracownika pracy za wynagrodzeniem, za cel niniejszego studium postawiono usystematyzowanie oraz analizę kilku świadczeń społecznych regulowanych w prawie pracy. Artykuł przedstawia świadczenia społeczne wypłacane przez pracodawcę na rzecz pracownika. Pracodawca został zobowiązany do realizacji takich świadczeń, jak wynagrodzenie urlopowe, wynagrodzenie chorobowe, wynagrodzenie za czas podnoszenia kwalifikacji zawodowych, świadczenia związane z ochroną rodzicielstwa, wynagrodzenie za czas zwolnień okolicznościowych, odprawy pracownicze, dodatki wyrównawcze dla pracowników szczególnie chronionych, wynagrodzenie za czas badań medycyny pracy oraz świadczenia wypłacane na podstawie ustawy o zakładowym funduszu świadczeń socjalnych.

KEYWORDS: allowance, employer, salary, severance pay employee, social benefits.

SŁOWA KLUCzowE: dodatek, odprawa pracownik, pracodawca, świadczenia społeczne, wynagrodzenie.

\section{WPROWADZENIE}

Motorem tworzenia wszelkiego rodzaju prawa jest ogólnie ujęta potrzeba, brak potrzeby oraz niespełnienie potrzeby człowieka, a w przypadku prawa pracy - pracownika (Duniewska, 2012, s. 1-49). Jedną z funkcji prawa pracy, poza ochronną i organizacyjną, jest funkcja zaspokajania potrzeb (Dzienisiuk, 2016, s. 50). Zgodnie z Kodeksem pracy (Dz.U. z 1974 r. nr 24, poz. 141 z późn. zm., dalej także: k.p.) do obowiązków pracodawcy należy zaspokajanie potrzeb społecznych pracowników wynikających z przepisów prawa pracy. „Przepis art. 16 k.p. nadaje rangę podstawowej zasady prawa pracy obowiązkowi pracodawcy zaspokajania potrzeb życiowych pracowników, które nie mieszczą się w treści stosunku pracy, czyli w sferze wzajemnych praw i obowiązków stron związanych $\mathrm{z}$ wykonywaniem przez pracownika pracy za wynagrodzeniem" (Zieliński, 2011, s. 102). Problematyka świadczeń społecznych w prawie pracy to istotny w sensie badawczym, a przy tym niezmiernie ważny i nieprzerwanie aktualny temat. Wobec wagi istoty obowiązku pracodawcy zaspokajania potrzeb życiowych pracowników, które nie wypływają $\mathrm{z}$ treści stosunku pracy, za cel niniejszego studium postawiono usystematyzowanie oraz analizę kilku świadczeń społecznych regulowanych w prawie pracy. 


\section{ŚWIADCZENIA ZASPOKAJAJĄCE POTRZEBY SPOŁECZNE PRACOWNIKÓW}

Zgodnie $z$ art. 3 Kodeksu pracy pracodawcą jest zatrudniająca pracowników osoba fizyczna lub jednostka organizacyjna choćby nie posiadała osobowości prawnej. Natomiast pracownik to osoba zatrudniona na podstawie umowy o pracę, powołania, wyboru, mianowania lub spółdzielczej umowy o pracę (art. 2 k.p.). Świadczenia społeczne sensu largo związane z pracą to te wypłacane przez pracodawcę na rzecz pracownika (Mędrala, 2019, s. 27), obejmują one potrzeby bytowe, rodzinne oraz te związane $z$ wieloma życiowymi ryzykami socjalnymi (takich jak starość, choroba, potrzeba odpoczynku, utrata zdolności do pracy, ochrona życia rodzinnego, rodzicielstwa oraz potrzeba samorealizacji społecznej i kulturalnej) (Mędrala, 2019, s. 26). Ponadto pracodawca może realizować też świadczenia społeczne innego rodzaju na podstawie art. 16 k.p. („Pracodawca, stosownie do możliwości i warunków, zaspokaja bytowe, socjalne i kulturalne potrzeby pracowników”) w zw. z art. 94 pkt 8 k.p. („Pracodawca jest obowiązany w szczególności: zaspokajać w miarę posiadanych środków socjalne potrzeby pracowników”). Przeważająca większość przedmiotowych niewzajemnych świadczeń ma charakter obligatoryjny i roszczeniowy, jednak nie są one stałe ani periodyczne. Legitymacja do pobierania przedmiotowych świadczeń pojawia się w przypadku zaistnienia szczególnych okoliczności takich jak choroba, narodzenie się dziecka czy przejście na emeryturę.

\section{Publicznoprawna koncepcja prawa pracy}

Publicznoprawna koncepcja prawa pracy należy do stosunkowo nowych poglądów na prawo pracy. Zgodnie $z$ nią pracodawca wykonuje obowiązki ze sfery interesu publicznego, jedynie formalnie są to jego obowiązki własne, ale w istocie są to obowiązki wspólnoty w stosunku do słabszych. Są one narzucone pracodawcy w Kodeksie pracy przez państwo przy okazji stosunku zatrudnienia, co ma oznaczać, że pracodawca wykonuje funkcje z zakresu polityki społecznej za państwo i razem z państwem (Sobczyk, 2014, s. 54). Obowiązek ten jest różnie rozdzielany. Im mocniejszą ochronę zapewnia jedna ze stron, tym mniejszą gwarantuje druga. To dodatkowe obciążenie praco- 
dawcy wypływa z regulacji konstytucyjnych. Znajduje ono swoje uzasadnienie w koncepcji dobra wspólnego (art. 1), obowiązku obywateli troski o dobro wspólne (art. 82), zasadzie sprawiedliwości społecznej (art. 2) oraz ochronie godności człowieka (art. 30) (Sobczyk, 2013, s. 310). Główną funkcją przedmiotowych świadczeń jest funkcja społeczna, a dopiero w dalszej kolejności funkcja alimentarna, co wynika z głównej aksjologii tych świadczeń (Mędrala, 2019, s. 92). Należy dodać, że są one chronione zgodnie z tymi samymi zasadami co wynagrodzenie za pracę. Potwierdził to wyrok Sądu Najwyższego z 19 lutego 2004 r., który stanowi, że „odprawa emerytalna (art. $92^{1}$ k.p.) oraz nagroda jubileuszowa (art. $77^{3} \$ 3$ pkt 3 k.p.) podlegają ochronie przed potrąceniami (art. 87 k.p.) jak wynagrodzenie za pracę" (wyrok SN z 19.02.2004 r., sygn. II UK 264/03).

\section{PraWA PracoWnika WŚród PRAW CZŁOWIEKA}

Pojęcie praw człowieka (iura hominium) po raz pierwszy zostało spisane w 1537 r. Wywodzi się ono z tradycji prawa naturalnego, a jego rozpowszechnienie nastąpiło pod koniec XVIII wieku jako rozwinięcie jednej z wielu koncepcji prawa naturalnego (Voegelin, 1956, s. 16). Współczesna koncepcja praw człowieka, której odzwierciedleniem są międzynarodowe akty prawne, miała swój początek po II wojnie światowej, kiedy to zastanawiano się, jak nie dopuścić ponownie do tak wielkiej tragedii. U podstaw dzisiejszej prawnej ochrony praw człowieka stało zło wyrządzone ludziom w konkretnych okolicznościach (Piechowiak, 1999, s. 21). Preambuła Powszechnej Deklaracji Praw Człowieka - zbioru praw człowieka i zasad ich stosowania uchwalonego przez Zgromadzenie Ogólne ONZ rezolucją 217/III A 10 grudnia 1948 r. w Paryżu - stanowi: „nieposzanowanie i nieprzestrzeganie praw człowieka doprowadziło do aktów barbarzyństwa, które wstrząsnęły sumieniem ludzkości, i że ogłoszono uroczyście jako najwznioślejszy cel ludzkości dążenie do zbudowania takiego świata, w którym ludzie korzystać będą z wolności słowa i przekonań oraz z wolności od strachu i nędzy”. Prawa człowieka jako powszechne, fundamentalne, przyrodzone, niezbywalne i nienaruszalne (Łopatka, 2002, s. 9) nie wymagają uzasadnienia, uzasadnienia zaś wymagają odstępstwa od tych praw (Osiatyński, s. 2). Jednak aby prawa człowieka miały realne znaczenie, odstępstwa od nich muszą mieć swoje prawne konse- 
kwencje, musi także istnieć możliwość zastosowania procedury pozwalającej jednostce skutecznie bronić się przed ich naruszeniem (Nowicki, s. 7). Gdy prawa człowieka stanowią podstawę roszczeń, nabierają wielkiego znaczenia, którego nie można im przypisać, gdy są tylko szczytnymi ideałami. Pierwsze zbiory praw człowieka w postaci Powszechnej Deklaracji Praw Człowieka z 1948 r. oraz Europejskiej Konwencji Praw Człowieka z 1950 r. zawierają wyłącznie prawa obywatelskie i polityczne, dopiero później zaczęły pojawiać się prawa człowieka tzw. drugiej generacji, do których należą prawa socjalno-ekonomiczno-kulturalne, w tym prawa pracownicze. Prawa pracownicze zostały zagwarantowane w Międzynarodowym pakcie praw gospodarczych, społecznych i kulturalnych uchwalonym podczas konferencji ONZ w Nowym Jorku, na mocy rezolucji Zgromadzenia Ogólnego nr 2200A (XXI) z 16 grudnia 1966 r. Polska ratyfikowała ten międzynarodowy akt prawny 3 marca $1977 \mathrm{r}$.

\section{ŚWIAdCZENIA SPOŁECZNE W PRAWIE PRACY A PRAWO CZLOWIEKA DO SPOEECZNYCH PRAW SOCJALNYCH}

W literaturze można spotkać podział praw człowieka na zasadnicze trzy kategorie: wolności i prawa osobiste, wolności i prawa polityczne oraz prawa ekonomiczne, socjalne i kulturalne (Michalska, 1976, s. 173). W trzeciej z wymienionych kategorii praw wśród praw socjalnych mieszczą się pracownicze prawa człowieka, znajdując tym samym miejsce w prawach człowieka drugiej generacji. Prawa drugiej generacji przybierają zazwyczaj formę „wolności od”, natomiast prawa pierwszej generacji to zwykle „prawo do”. Dyskusja o coraz szerszym zasięgu praw człowieka stale się toczy, pojawiają się postulaty o włączeniu do istniejącej listy, takich praw i wolności jak: wolność od wykluczenia społecznego, prawo do bezpieczeństwa ekonomicznego czy też prawo do życia w zdrowym środowisku (zob. więcej: Ziemblicki, 2015, s. 214-230). Aktualnie zaczyna się coraz więcej mówić o współzależności obu generacji praw, bez jednych nie można bowiem korzystać z drugich, jak na przykład bez minimum praw socjalnych nie można korzystać z praw osobistych i politycznych. Prawa socjalne mają charakter pozytywny, większości z nich odpowiadają konkretne świadczenia ze strony państwa, przez co pań- 
stwo staje się odpowiedzialne za przestrzeganie tych praw (Łopatka, 2002, s. 11). Prawa socjalne mają silne podłoże moralne, zapewnienie bowiem bezpieczeństwa ekonomicznego człowiekowi, który sam nie jest w stanie go sobie zapewnić, jest obowiązkiem społecznym (Mędrala, 2019, s. 231). Zwykle jednak państwo kształtuje swoją politykę społeczną w taki sposób, by prawa te były realizowane w ramach stosunków prywatnych (Osiatyński, 2011, s. 175), w przypadku zaś prawa pracownika do świadczeń społecznych jest inaczej - to pracodawca zostaje obciążony ich realizacją.

\section{KONSTRUKCJA ŚWIADCZEŃ SPOŁECZNYCH W PRAWIE PRACY}

Pracodawca został zobowiązany do realizacji świadczeń społecznych na rzecz pracownika, wśród których znalazło się wynagrodzenie urlopowe, wynagrodzenie chorobowe, wynagrodzenie za czas podnoszenia kwalifikacji zawodowych, świadczenia związane z ochroną rodzicielstwa, wynagrodzenie za czas zwolnień okolicznościowych, odprawy pracownicze, dodatki wyrównawcze dla pracowników szczególnie chronionych, wynagrodzenie za czas badań medycyny pracy oraz świadczenia wypłacane na podstawie ustawy o zakładowym funduszu świadczeń socjalnych.

\section{Wynagrodzenie urlopowe}

Wynagrodzenie urlopowe to świadczenie ustawowe o charakterze roszczeniowym, obligatoryjnym, powszechnym, nieselektywnym, niewzajemnym oraz bezwarunkowym. Prawo do tego świadczenia wypływa z art. 66 ust. 2 Konstytucji stanowiącego o prawie pracownika do dni wolnych od pracy i corocznych płatnych urlopów. Funkcja prawa do tego świadczenia polega na zapewnieniu przestrzeni czasu wolnego pracownikowi przy jednoczesnym zagwarantowaniu zabezpieczenia finansowego. Wynagrodzenie urlopowe doczekało się wielu koncepcji wyjaśniających jego istotę, jedną z nich stanowi koncepcja odpłaty, zgodnie z którą udzielenie urlopu to świadczenie pracodawcy na rzecz pracownika w zamian za wykonywaną pracę (zob. więcej: Bigaj, 2015). Ma ono gwarantować możliwość rozwoju poza pracą, czyli realizację prawa do wolności od pracy (Sobczyk, 2013, s. 310). Zgodnie z art. 172 Kodeksu pracy, pracownik otrzymuje za czas urlopu wynagrodzenie, jakie 
otrzymałby, gdyby w tym czasie pracował, co oznacza, że podczas płatnego urlopu pracownikowi przysługuje $100 \%$ wynagrodzenia.

\section{Wynagrodzenie chorobowe}

Wynagrodzenie chorobowe jest świadczeniem ustawowym mającym charakter roszczeniowy, obligatoryjny, powszechny, nieselektywny, niewzajemny oraz bezwarunkowy. Świadczenie to stanowi koszt ryzyka związanego z chorobą pracownika i polega na tym, że pracownik zachowuje prawo do całego wynagrodzenia (lub jego części), podczas gdy nie może świadczyć pracy na rzecz pracodawcy z powodu choroby. Taki model obciążania pracodawcy kosztami wpisuje się w zawartą w art. 20 Konstytucji zasadę społecznej gospodarki rynkowej, korzystanie z pracy pracownika stanowi bowiem uzasadnienie dla obciążenia pracodawcy obowiązkami, które wykraczają poza prostą ekwiwalentność świadczeń (Pisarczyk, 2008, s. 253). Należy tutaj wskazać także na art. 67 Konstytucji, który stanowi główne źródło dla omawianego prawa, stanowiąc, że obywatel ma prawo do zabezpieczenia społecznego w razie niezdolności do pracy ze względu na chorobę lub inwalidztwo. Zgodnie z art. 92 Kodeksu pracy pracownik otrzymuje $80 \%$ wynagrodzenia za czas niezdolności do pracy wskutek choroby lub odosobnienia w związku z chorobą zakaźną, natomiast $100 \%$ wynagrodzenia za czas niezdolności do pracy pracownik otrzymuje wskutek wypadku w drodze do pracy lub z pracy albo choroby przypadającej w czasie ciąży, a także podczas poddania się niezbędnym badaniom lekarskim przewidzianym dla kandydatów na dawców komórek, tkanek i narządów oraz poddania się zabiegowi pobrania tychże. Przez pierwsze 33 dni świadczenie pochodzi od pracodawcy, przez kolejne od Zakładu Ubezpieczeń Społecznych. Wysokość wynagrodzenia chorobowego zgodnie $z$ art. 36 ustawy o świadczeniach pieniężnych $\mathrm{z}$ ubezpieczenia społecznego $\mathrm{w}$ razie choroby i macierzyństwa jest zależna wyłącznie od wysokości wynagrodzenia za pracę otrzymywanego w ciągu ostatnich 12 miesięcy (Dz.U. z 2017 r. poz. 1368 z późn. zm.).

\section{Wynagrodzenie za czas podnoszenia kwalifikacji zawodowych}

Wynagrodzenie za czas podnoszenia kwalifikacji zawodowych to świadczenie ustawowe, fakultatywne, indywidualne, selektywne, niewzajemne i warunkowe. Podstawowego źródła prawa do tego świadczenia można doszukiwać się 
już w Konstytucji (Mędrala, 2019, s. 474-476), gdzie art. 70 stanowi, że każdy ma prawo do nauki. Zgodnie $\mathrm{z}$ art. $103^{1} \$ 2$ Kodeksu pracy pracownikowi podnoszącemu kwalifikacje zawodowe przysługuje urlop szkoleniowy oraz zwolnienie z całości lub części dnia pracy, na czas niezbędny, by punktualnie przybyć na obowiązkowe zajęcia oraz na czas ich trwania, natomiast $\$ 3$ tego samego przepisu stanowi, iż za czas urlopu szkoleniowego oraz za czas zwolnienia z całości lub części dnia pracy pracownik zachowuje prawo do wynagrodzenia, które przysługuje mu za pracę, czyli 100\% wymiaru tego świadczenia. Pracodawca nie ma jednak obowiązku udzielenia urlopu szkoleniowego, co stanowi mankament obecnej w Kodeksie pracy konstrukcji tego prawa.

\section{Świadczenia związane z ochroną rodzicielstwa}

Świadczenia związane $\mathrm{z}$ ochroną rodzicielstwa należą do świadczeń ustawowych o charakterze roszczeniowym, obligatoryjnym, powszechnym (dla określonej kategorii osób), nieselektywnym, niewzajemnym oraz bezwarunkowym. Zgodnie z Konwencją nr 183 Międzynarodowej Organizacji Pracy, dokonującej w 2000 roku rewizji Konwencji dotyczącej ochrony macierzyństwa z 1952 r., fundamentem świadczeń związanych z ochroną rodzicielstwa są przepisy konstytucyjne gwarantujące ochronę socjalnych praw człowieka związanych $\mathrm{z}$ rodzicielstwem. Zapewnienie ochrony podczas ciąży stanowi bowiem wspólny obowiązek rządu i społeczeństwa. Zgodnie z art. 18 polskiej Konstytucji macierzyństwo i rodzicielstwo znajdują się pod ochroną i opieką Rzeczypospolitej Polskiej, ponadto art. 71 ustawy zasadniczej stanowi, iż matka przed urodzeniem dziecka i po jego urodzeniu ma prawo do szczególnej pomocy władz publicznych. Pomoc ta realizowana jest poprzez zapewnienie świadczeń podczas ciąży oraz po urodzeniu dziecka. Podczas ciąży oraz karmienia dziecka piersią pracodawca ma obowiązek dostosować warunki pracy do stanu pracownicy, począwszy od zmiany jej rozkładu i rodzaju pracy (art. 178 k.p.), po zwolnienie jej z obowiązku świadczenia pracy (art. 179 k.p.), ponadto podczas ciąży pracownica otrzymuje odpłatne zwolnienie na czas badań lekarskich (art. 185 k.p.). Po narodzinach dziecka pracownicy przysługuje wypłata wynagrodzenia za czas przerwy dla matek karmiących piersią (art. 187 k.p.) oraz odpłatne zwolnienie na czas opieki nad dzieckiem zdrowym (art. 188 k.p.). W każdym z wymienionych przypadków 
pracownica otrzymuje wynagrodzenie w pełnym 100\% wymiarze. Istotę wymienionych świadczeń stanowi ochrona rodzicielstwa poprzez utrzymanie wysokości wynagrodzenia pracownicy sprzed okresu ciąży, podczas ciąży oraz po ciąży (por. Mędrala, 2019, s. 492-493), co zapewnić ma zabezpieczenie jej przed obniżeniem dochodu na czas, gdy pojawią się szczególne potrzeby.

\section{Wynagrodzenie za czas zwolnień okolicznościowych}

Wynagrodzenie za czas zwolnień okolicznościowych (zwanych „urlopami okolicznościowymi”) obejmuje świadczenia, które są powszechne, nieselektywne, obligatoryjne oraz niewzajemne. Ich celem jest realizacja potrzeb społecznych lub socjalnych pracowników. Okoliczności, które uzasadniają zwolnienie pracownika ze świadczenia pracy przy zachowaniu pełnego 100\% wynagrodzenia za ten czas z przyczyn społecznych, zostały określone w rozporządzeniu Ministra Pracy i Polityki Socjalnej w sprawie sposobu usprawiedliwiania nieobecności w pracy oraz udzielania pracownikom zwolnień od pracy (Dz.U. z 2014 r. poz. 1632). Zgodnie z $\$ 15$ tego rozporządzenia w przypadku wydarzeń, które dotyczą bezpośrednio samego pracownika lub jego najbliższych, przysługują mu 2 dni zwolnienia (własny ślub, urodzenie dziecka, zgon i pogrzeb małżonka lub dziecka, ojca, matki, ojczyma, macochy), natomiast gdy zajdą okoliczności dotyczące dalszej rodziny, przysługuje mu 1 dzień zwolnienia (ślub dziecka, zgon i pogrzeb siostry, brata, teściowej, teścia, babki, dziadka, a także osoby będącej na utrzymaniu lub pod opieką pracownika). Natomiast zgodnie z $\$ 12$ tego rozporządzenia realizacja potrzeb socjalnych pracowników poprzez zwolnienie pracownika ze świadczenia pracy i wypłatę $100 \%$ wynagrodzenia przysługuje za czas oddawania krwi w stacji krwiodawstwa, wykonywania badań zleconych przez stację krwiodawstwa. Należy dodać, że okoliczność taką stanowi również nadejście katastrofy naturalnej, jaką jest powódź. Zgodnie bowiem z art. 8 ustawy o szczególnych rozwiązaniach związanych z usuwaniem skutków powodzi faktyczna niemożność świadczenia pracy w związku z powodzią stanowi podstawę usprawiedliwienia nieobecności pracownika w pracy (Dz.U. z 2011 r. nr 234, poz. 1385). Jednakże w związku z tą okolicznością nie przysługuje pracownikowi prawo do pełnego wynagrodzenia, ale do „odpowiedniej części minimalnego wynagrodzenia za pracę”. Ponadto zgodnie z art. 37 Kodeksu pracy pracodawca ma obowiązek zwolnić 
pracownika podczas okresu wypowiedzenia na czas poszukiwania pracy. Wymiar zwolnienia wynosi 2 dni w okresie 2-tygodniowego i miesięcznego wypowiedzenia, natomiast 3 dni w okresie wypowiedzenia 3-miesięcznego. Istotą tej regulacji jest ochrona pracownika przed wykluczeniem społecznym z powodu braku pracy oraz zachowanie ciągłości zabezpieczenia finansowego.

\section{Odprawy pracownicze}

Odprawy pracownicze należą do jednorazowych świadczeń ustawowych o charakterze powszechnym, roszczeniowym, obligatoryjnym, nieselektywnym i niewzajemnym. Odprawy pracownicze można podzielić na te, które realizują cele o charakterze publicznym, oraz te, które spełniają potrzeby socjalne uprawnionych pracowników. Do pierwszego typu odpraw należą odprawy wypłacane przy zaistnieniu dwóch okoliczności: wygaśnięcia mandatu pracownika, który w związku z wyborem nie pozostawał na urlopie bezpłatnym (zgodnie z art. 75 k.p. odprawa równa jest wysokości miesięcznego wynagrodzenia) oraz powołania do zasadniczej, okresowej lub terytorialnej służby wojskowej (zgodnie $\mathrm{z}$ art. 125 ustawy o powszechnym obowiązku obrony Rzeczpospolitej Polskiej, odprawa równa jest wysokości 2-tygodniowego wynagrodzenia) (Dz.U. z 2018 r. poz. 1459 z późn. zm.). Drugą kategorię odpraw obejmują: odprawa pośmiertna (zgodnie $z$ art. 93 k.p. odprawa równa jest wysokości 1-, 3- lub 6-miesięcznego wynagrodzenia), odprawa emerytalno-rentowa (zgodnie z art. $92^{1} \$ 1$ k.p. odprawa równa jest wysokości miesięcznego wynagrodzenia) oraz odprawa $z$ tytułu zwolnienia z przyczyn niedotyczących pracownika (zgodnie $\mathrm{z}$ art. 8 ustawy o szczególnych zasadach rozwiązywania $\mathrm{z}$ pracownikami stosunków pracy z przyczyn niedotyczących pracowników, w razie grupowego zwolnienia odprawa równa jest wysokości 1-, 2- lub 3-miesięcznego wynagrodzenia). Celem odpraw pracowniczych jest ochrona interesów pracownika w szczególnych okolicznościach zakończenia stosunku pracy oraz zapewnienie mu przynajmniej czasowej stabilizacji finansowej (Mędrala, 2019, s. 391).

\section{Dodatki wyrównawcze dla pracowników szczególnie chronionych}

Dodatek wyrównawczy dla pracowników szczególnie chronionych to świadczenie ustawowe, roszczeniowe, obligatoryjne, selektywne i niewzajemne. Pracownikiem szczególnie chronionym jest pracownik posiadający 
ze strony prawa szczególną ochronę ze względu na jego wiek, rodzicielstwo oraz pełnione szczególne obowiązki (które pełni zazwyczaj w zakładowej organizacji związkowej) (zob. więcej: Dz.U. z 2003 r. nr 90, poz. 844 z późn. zm.). Dodatek wyrównawczy otrzymuje pracownik szczególnie chroniony, w sytuacji gdy zostanie przeniesiony na nowe stanowisko pracy, a jego wynagrodzenie ulegnie zmniejszeniu. Wysokość dodatku wyrównawczego jest ustalana tak, by wraz z nowym wynagrodzeniem stanowiło kwotę równą wynagrodzeniu poprzedniemu. Celem tego świadczenia jest zapewnienie stabilności zatrudnienia oraz utrzymania poziomu życia.

\section{Wynagrodzenie za czas badań medycyny pracy}

Wynagrodzenie za czas badań medycyny pracy to świadczenie ustawowe, powszechne, bezwarunkowe oraz nieselektywne. Badania medycyny pracy są niezbędne do tego, by realizowane były konstytucyjne gwarancje bezpiecznych i higienicznych warunków pracy (art. 66 Konstytucji), które konkretyzowane są na gruncie Kodeksu pracy w art. 15. Pracodawca obciążony jest przez prawo kosztami związanymi z ochroną życia i zdrowia pracownika w związku z wykonywaniem przez niego pracy, przez co pracownik ma prawo do pełnego, 100\% wynagrodzenia za czas niewykonywania pracy w związku z przeprowadzanymi badaniami lekarskimi z zakresu medycyny pracy (art. $229 \$ 3$ k.p.) oraz $\mathrm{z}$ odbywaniem szkoleń BHP w godzinach pracy i na koszt pracodawcy (art. $237^{3}$ k.p.). Kwestie te są istotne ze względu na znaczenie, jakie ma przeszkolenie BHP oraz stan zdrowia pracownika dla efektywnego wypełniana przez niego obowiązków pracowniczych.

\section{Świadczenia wypłacane na podstawie ustawy o zakładowym funduszu świadczeń socjalnych}

Zakładowy fundusz świadczeń socjalnych (dalej także: ZFSŚ) zgodnie $\mathrm{z}$ art. 3 ust. 1 ustawy o zakładowym funduszu świadczeń socjalnych, tworzony jest obligatoryjnie przez pracodawców jednostek budżetowych i samorządowych oraz pozostałych rodzajów zakładów pracy, jeśli zatrudniają minimum 50 pracowników w przeliczeniu na pełne etaty (Dz.U. z 1994 r. nr 43, poz. 163). Fundusz obejmuje środki finansowe gromadzone przez pracodawcę na osobnym rachunku bankowym w celu wykorzystania ich na wspar- 
cie socjalne pracowników. Ustanowienie instytucji prawnej, jaką jest ZFSŚ, to wyraz społecznej, w tym socjalnej, funkcji pracodawcy (Mędrala, 2019, s. 513). Celem świadczeń wypłacanych pracownikom $z$ funduszu jest między innymi promocja wypoczynku, kultury, integracji oraz rodziny. Z ZFSŚ finansowane są dla pracowników imprezy integracyjne, kulturalne i sportowe oraz dofinansowywany jest wypoczynek, żłobki oraz przedszkola. Ponadto możliwe jest otrzymywanie z zasobów ZFSŚ świadczeń urlopowych oraz zapomóg losowych.

\section{Podsumowanie}

Prawa pracownicze zaliczane są do praw człowieka drugiej generacji obejmujących prawa socjalne, ekonomiczne i kulturalne. Kodeks pracy nadaje rangę podstawowej zasady prawa pracy obowiązkowi pracodawcy zaspokajania potrzeb życiowych pracowników, które nie mieszczą się w treści stosunku pracy. Przedstawiony w sposób usystematyzowany przegląd oraz analiza świadczeń społecznych regulowanych w prawie pracy wskazuje na dużą różnorodność tych świadczeń. Różnorodność ta implikowana jest wieloma potrzebami pracownika jako jednostki ludzkiej, której dotyczy szeroki wachlarz sytuacji życiowych. Pracodawca został zobowiązany do realizacji zaspokajania wskazanych potrzeb życiowych pracowników poprzez świadczenia społeczne, które tworzą rozbudowany katalog obejmujący wynagrodzenie urlopowe, wynagrodzenie chorobowe, wynagrodzenie za czas podnoszenia kwalifikacji zawodowych, świadczenia związane z ochroną rodzicielstwa, wynagrodzenie za czas zwolnień okolicznościowych, odprawy pracownicze, dodatki wyrównawcze dla pracowników szczególnie chronionych, wynagrodzenie za czas badań medycyny pracy, świadczenia wypłacane na podstawie ustawy o zakładowym funduszu świadczeń socjalnych. Wymienione świadczenia społeczne stanowią koszt pracodawcy, jaki ponosi on w związku z zatrudnianiem pracowników; który narzucony jest głównie przez Kodeks pracy. Ustawodawca zapewnia przedmiotowym świadczeniom taką samą ochronę jak wynagrodzeniu za pracę, co przesądza o ich dużym znaczeniu. Zgodnie ze zdaniem prof. Pisarczyka znajduje to swoje uzasadnienie w odniesieniu do konstytucyjnej zasady gospodarki rynkowej, która wskazuje na to, że obciążenie pracodawcy wypłatą przedstawionych świadczeń uzasadnione jest korzystaniem przez pracodawcę z pracy pracownika. Uprawnienie do omawianych świadczeń społecznych wypływa 
także z innych konstytucyjnych zasad, takich jak koncepcja dobra wspólnego, obowiązek obywateli troski o dobro wspólne, zasada sprawiedliwości społecznej oraz ochrona godności człowieka, co podkreśla się w publicznoprawnej koncepcji prawa pracy, która znajduje coraz szersze grono zwolenników.

\section{Bibliografia}

Bigaj A. (2015), Prawo do urlopu wypoczynkowego, Warszawa: Wolters Kluwer. ISBN 9788326484391.

Bosak M. (red.) (2014), Funkcja ochronna prawa pracy a wyzwania wspótczesności, Warszawa: C.H. Beck. ISBN 9788325563493.

Duniewska Z. (2012), Prawo administracyjne materialne. W: (red.) R. Hauser, Z. Niewiadomski, A. Wróbel, System Prawa Administracyjnego, t. 7, Warszawa: C.H. Beck, s. 1-49. ISBN 9788325563493.

Dzienisiuk D. (2016), Prawo pracy a prawo ubezpieczeń społecznych, Warszawa: Difin. ISBN 9788380851597.

Konstytucja Rzeczypospolitej Polskiej z 2 kwietnia 1997 r. (Dz.U. z 1997 r. nr 78, poz. 483 z późn. zm.).

Konwencja nr 183 Międzynarodowej Organizacji Pracy dotycząca rewizji Konwencji dotyczącej ochrony macierzyństwa (zrewidowana w 2000 r.), z 1952 r.

Łopatka A. (2002), Jednostka, jej prawa człowieka, Warszawa: Oficyna Wydawnicza Wyższej Szkoły Handlu i Prawa im. Ryszarda Łazarskiego. ISBN 8388690256.

Mędrala M. (2019), Społeczny charakter świadczeń w polskim prawie pracy, Warszawa: Wolters Kluwer. ISBN 9788381603010.

Michalska A. (1976), Podstawowe prawa człowieka w prawie wewnętrznym a Pakty Praw Człowieka, Warszawa: Wydawnictwo Prawnicze.

Nałęcz M. (red.) (2019), Przepisy i zestawienia kadrowe. Obowiązki pracodawcy wobec pracowników, Warszawa: C.H. Beck. ISBN 9788381583534.

Nowicki M., Co to sa prawa człowieka. Pobrane z: http://www.hfhrpol.waw.pl/pliki/ MNowicki_CoToSa.pdf (dostęp: 22.08.2019 r.).

Osiatyński W. (2011), Prawa człowieka i ich granice, Kraków: Społeczny Instytut Wydawniczy Znak. ISBN 9788324015139.

Osiatyński W., Wprowadzenie do praw człowieka, Helsińska Fundacja Praw Człowieka. Pobrane z: https://www.hfhr.pl/wp-content/uploads/2016/02/WiktorOsiatynsk iWprowadzenieDoPojeciaPrawCzlowieka.pdf (dostęp 22.08.2019 r.).

Piechowiak M. (1999), Filozofia praw człowieka: prawa człowieka w'świetle ich międzynarodowej ochrony, Lublin: Towarzystwo Naukowe KUL. ISBN 8387703710. 
Pisarczyk Ł. (2008), Ryzyko pracodawcy, Warszawa: Wolters Kluwer, s. 253. ISBN 9788376010076.

Powszechna Deklaracja Praw Człowieka uchwalona przez Zgromadzenie Ogólne ONZ rezolucją 217/III A 10 grudnia 1948 roku w Paryżu.

Rozporządzenie Ministra Pracy i Polityki Socjalnej z 15 maja 1996 r. w sprawie sposobu usprawiedliwiania nieobecności w pracy oraz udzielania pracownikom zwolnień od pracy (Dz.U. z 2014 r. poz. 1632).

Sobczyk A. (2013), Prawo i człowiek pracujący - między ochrona godności a równości. W: (red.) M. Skąpski, K.A. Sobczyk, Prawo pracy w świetle Konstytucji RP. Tom I. Teoria publicznego i prywatnego indywidualnego prawa pracy, Warszawa: C.H. Beck, t. 1, s. 31-59. ISBN 9788325549213.

Suknarowska-Drzewiecka E., Wojciechowski P. (2010), Podnoszenie i uzupetnianie kwalifikacji zawodowych przez pracowników, Warszawa: C.H. Beck. ISBN 9788325522995.

Ustawa z 13 marca 2003 r. o szczególnych zasadach rozwiązywania z pracownikami stosunków pracy z przyczyn niedotyczących pracowników (Dz.U. z 2003 r. nr 90, poz. $844 \mathrm{z}$ późn. zm.).

Ustawa z 16 września 2011 r. o szczególnych rozwiązaniach związanych z usuwaniem skutków powodzi (Dz.U., z 2011 r. nr 234, poz. 1385).

Ustawa z 21 listopada 1967 r. o powszechnym obowiązku obrony Rzeczpospolitej Polskiej (Dz.U. z 2018 r. poz. 1459 z późn. zm.).

Ustawa z 25 czerwca 1999 r. o świadczeniach pieniężnych z ubezpieczenia społecznego w razie choroby i macierzyństwa (Dz.U. z 2017 r., poz. 1368 z późn. zm.).

Ustawa z 26 czerwca 1974 r. - Kodeks pracy (Dz.U. 1974 r., nr 24, poz. 141 z późn. zm.).

Ustawa z 4 marca 1994 r. o zakładowym funduszu świadczeń socjalnych (Dz.U. z 1994 r. nr 43 z poz. 163).

Voegelin E. (1956). Order and History, t. 1, Baton Roude: Louisiana State University Press.

Wyrok Sądu Najwyższego z 19 lutego 2004 r., sygn. II UK 264/03.

Zieliński T., Goździewicz G. (2011). Kodeks pracy. Komentarz, Warszawa: C.H. Beck.

Ziemblicki B. (2015). Kilka refleksji nad relacjami pomiędzy ochrona środowiska i prawami człowieka. W: (red.) E. Karska, Globalne problemy ochrony praw człowieka, Warszawa: Uniwersytet Kardynała Stefana Wyszyńskiego, s. 214-230. ISBN 9788364298028 . 